
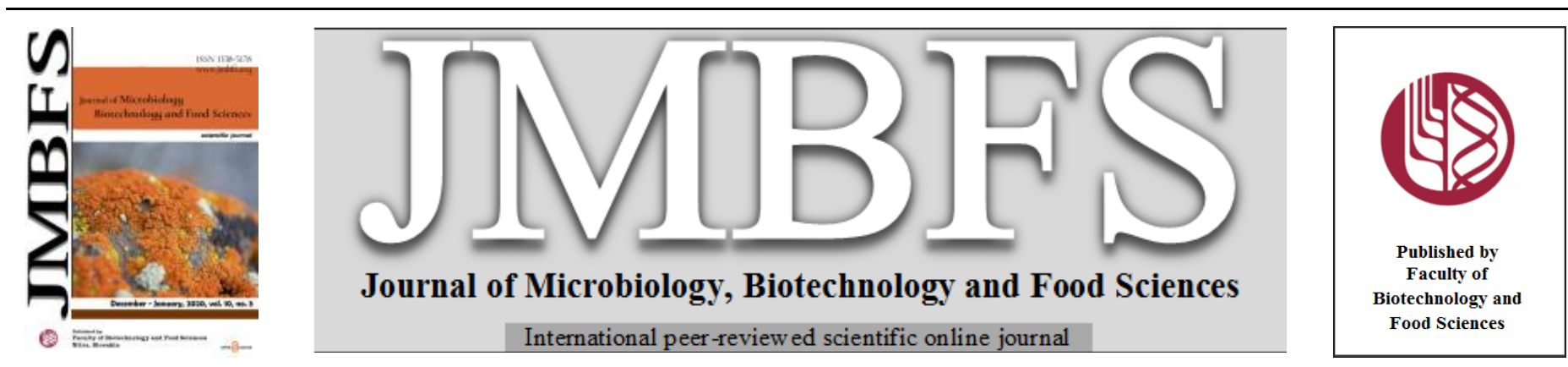

\title{
MODELING AND OPTIMIZATION OF THE PULSED VACUUM OSMOTIC DEHYDRATION (PVOD) PROCESS OF CARROTS IN A TERNARY SOLUTION BY RESPONSE SURFACE METHODOLOGY
}

\author{
Md. Raihanul Haque ${ }^{* 1}$, Md. Mojaffor Hosain ${ }^{2}$, Mohammad Atikur Rahman $^{2,3}$, Md. Murtuza Kamal ${ }^{2}$, Shakti Chandra Mondal ${ }^{2,4}$, \\ A.K.M. Monjurul Islam ${ }^{l}$
}

$\operatorname{Address(es):~}$

${ }^{1}$ Department of Food Engineering and Technology, Faculty of Engineering, Hajee Mohammad Danesh Science and Technology University, Dinajpur-5200, Bangladesh.

${ }^{2}$ Department of Food Processing and Preservation, Faculty of Engineering, Hajee Mohammad Danesh Science and Technology University, Dinajpur-5200, Bangladesh. ${ }^{3}$ Department of Food Science and Nutrition, Zhejiang University, Hangzhou 310058, China.

${ }^{4}$ Center for International Education and Development, Keimyung University, Dalgubeoldaero, Dalseo-Gu Daegu, Republic of Korea.

*Corresponding author: fetraihan12@hstu.ac.bd

doi: $10.15414 / j m b f s .2020 .10 .3 .454-460$

ARTICLE INFO

Received 16. 1. 2020

Revised 13. 8. 2020

Accepted 23. 9. 2020

Published 1. 12. 2020

Regular article

OPEN $\partial$ ACCESS

\begin{abstract}
Optimization of the pulsed vacuum osmotic dehydration (PVOD) process of carrot slices in a ternary solution was carried out using the response surface methodology. During PVOD, the vacuum pulse was applied at the beginning of the process for $10 \mathrm{~min}$ at a reduced pressure of $500 \mathrm{~mm}$ of $\mathrm{Hg}$ throughout all the experiments. After that, the osmotic dehydration process was continued at atmospheric pressure according to the central composite rotatable design (CCRD). The effects of temperature $\left(35-55^{\circ} \mathrm{C}\right)$, sugar concentration $(40-$ $\left.50^{\circ} \mathrm{Brix}\right)$, salt concentration (5-15\%) and osmosis time restored at atmospheric pressure (10-240 $\mathrm{min}$ ) on the responses viz. water loss $(\mathrm{WL})$, solute gain $(\mathrm{SG})$ and colour difference $(\Delta \mathrm{E})$ of the dehydrated samples were assessed and statistically optimized through the desirability function approach. The models obtained for water loss, solute gain and colour difference were found suitable to describe the experimental data. It was found that the time restored at atmospheric pressure has the most significant effect on the responses at the $95 \%$ confidence level. The optimum condition was found at a temperature of $50^{\circ} \mathrm{C}$, sugar concentration of $45.47^{\circ} \mathrm{Brix}$, salt concentration of $7.50 \%$, and restoration time of $67.50 \mathrm{~min}$. At these optimum conditions, the water loss, solute gain and colour difference were $42.61 \%$, $10.42 \%$ and 4.38 , respectively. The predicted optimum values for independent linear variables were validated by performing triplicate experiments and the simulated data were come across similar with the experimental ones.
\end{abstract}

Keywords: Drying, pulsed vacuum osmotic dehydration, response surface methodology, sugar, salt

\section{INTRODUCTION}

In Bangladesh, above $30-40 \%$ of fresh fruits and vegetables are spoiled due to lack of proper and timely processing. In addition, the main cause of spoilage of fresh fruits and vegetables are their high moisture content $(>80 \%)$ in nature (Karim and Hawlader, 2005; Orsat et al., 2006). Thus, the fruits and vegetables are highly perishable, requiring food preservation techniques to maintain shelf life and quality (Singh et al., 2014; Gandolfi et al., 2018). These products are generally preserved by different drying techniques (Nijhuis $\boldsymbol{e t}$ al., 1998). The main aim of drying is to increase the shelf life of products by reducing their water activity. It also helps to reduce bulk volume and weight of products, decreasing storage and transportation costs (Reinert et al., 2018). However, drying is an expensive energy-intensive process and expends about 20$25 \%$ of the energy used by the food industry. The energy efficiency and quality of dried product are two important critical key parameters in food drying (Kumar et al., 2014). Therefore, osmotic dehydration is one of the promising solutions for improving energy efficiency and product quality. This is because osmotic dehydration (OD) reduces $20-30 \%$ of energy consumption during final drying of the food product. Apart from this, it improves product quality such as the flavor, color and the textural properties of an ultimate product by lowering thermal damage during drying (Lenart, 1996; Shete et al., 2018).

Osmotic dehydration is a process in which water is partly removed by dipping foods, mostly fruits and vegetables in hypertonic solutions. The diffusion of water from plant tissue to the hypertonic solution is owing to osmotic pressures, which is taken place through a semipermeable membrane. Moreover, osmotic dehydration is a simple, economical process and requires a remarkably small energy during food processing (Shi and Maguer, 2002; Sagar and Kumar, 2010). The pulsed vacuum osmotic dehydration (PVOD) is an osmotic treatment, which performed at a reduced pressure during beginning of the process, accompanied by an extensive period of osmotic dehydration at atmospheric pressure (Fante et al., 2011; Corrêa et al., 2016). This reduction of pressure promotes the removal of internal vapor or liquid from the food material while boosting the ingress of an outermost osmotic solution through a hydrodynamic mechanism (HDM). The HDM creates a pressure gradient because of the combined action of capillary flow and pressure changes which bring down on the porous structures of food tissue (Corrêa et al., 2010; An et al., 2013). Several researchers conducted research on optimization of osmotic dehydration of carrots (Rastogi and Raghavarao, 1997; Singh et al., 2008). However, despite the wide literature available only few papers reported on the optimization of PVOD of carrots in a ternary solution of sugar and salt. The efficiency of dehydration process and lycopene reserving was also improved when the ternary solution of sugar-salt was used (Heredia et al., 2007; Corrêa et al., 2016).

Optimization of any dehydration process is therefore performed to ensure best alternative solution and get an acceptable quality product from a specified set of alternatives (Giri and Prasad, 2007). Response surface methodology (RSM) is effective statistical and mathematical techniques for performing experiments, building and developing models, and seeking for optimal conditions of desirable responses. The RSM tool aids to reduce the number of experimental runs that provide sufficient information for statistically valid results (Yadav $\boldsymbol{e t}$ al., 2012). Therefore, this study aimed to get the optimized process condition of PVOD of carrots in a ternary solution of sugar-salt regarding mass transfer parameters and colour differences than the fresh sample.

\section{MATERIAL AND METHODS}

\section{Procurement and preparation of raw materials}

Fresh carrots (Daucus carota L.) were collected from the local market and stored at $4-5^{\circ} \mathrm{C}$. Samples were washed with tap water to remove the dirt and after that were graded by size to eliminate the variations. Then, the carrots were cut into 
the thickness of $10 \pm 0.1 \mathrm{~mm}$ slices by the sharp stainless steel knife. Later, the moisture content of fresh carrots was determined by drying the samples in an oven at $105^{\circ} \mathrm{C}$ for $24 \mathrm{~h}$ until the final weight becomes constant (AOAC, 2005) The moisture content of carrots was calculated with the total weight of moisture loss of the samples after drying to the total weight of the fresh samples ratio (Rezaul et al., 2019). The initial moisture content of the carrot samples varied from $84.8 \%$ to $85.2 \%$ (wet basis).

\section{Osmotic solution preparation}

Osmotic solutions were prepared with food-grade sugar, salt and distilled water The distilled water was heated above ambient temperature and the hot water mixed with sugar and salt separately until predetermined concentrations attained The concentration of osmotic solutions was checked by a digital refractomete (HI96801, HANNA Instruments, USA). Then, the ternary solutions of sugar and salt were provided by mixing in a magnetic stirrer according to the experimental design.

\section{Pulsed vacuum osmotic dehydration (PVOD)}

The pulsed vacuum osmotic dehydration (PVOD) experiments were conducted in stainless steel cases. The temperature of the osmotic solution was restrained by a thermocouple and controlled by a thermostatic water bath. The vacuum pressure was got by a vacuum pump which settled in the vacuum dryer. The experiments were handled with the ternary solution of sugar and salt. The samples were placed in small stainless steel perforated boxes in a single layer, steeped in the osmotic solution and then wrapped with a sheet of aluminum film to prevent evaporation of the osmotic solution. In addition, the fruit to solution proportion was controlled relatively 1:45 for all experiments (Vieira et al., 2012). The vacuum pulse was kept in the first $10 \mathrm{~min}$ of each experiment at $500 \mathrm{~mm}$ of $\mathrm{Hg}$ (Corrêa et al., 2010; Viana et al., 2014). After the application of vacuum, the dehydration process was continued at atmospheric pressure for dehydration time ranges from 10 to 240 min (Singh et al., 2008; Corrêa et al., 2016). Afterwards the osmotic process, the samples were removed from the osmotic solutions and rinsed with tap water to stop the dehydration process. The samples were dried with absorbent paper to remove free water present on the surface. The samples were weighed and subsequently $10 \mathrm{~g}$ of samples were put into the petri-dish for determination of final moisture content in an oven at $105^{\circ} \mathrm{C}$ for $24 \mathrm{~h}$ (AOAC, 2005)

\section{Determination of mass transfer parameters}

The water loss (WL) and solute gain (SG) were calculated in accordance with the equations 1 and 2 (El-Aouar et al., 2006).

$$
\mathrm{WL}(\%)=\frac{\left(\mathrm{w}_{\mathrm{i}} \mathrm{X}_{\mathrm{i}}-\mathrm{w}_{\mathrm{f}} \mathrm{X}_{\mathrm{f}}\right)}{\mathrm{w}_{\mathrm{i}}} \times 100
$$

$$
\mathrm{SG}=\frac{\left(w_{\mathrm{f}}\left(1-\frac{X_{\mathrm{f}}}{100}\right)-\mathrm{w}_{\mathrm{i}}\left(1-\frac{\mathrm{X}_{\mathrm{i}}}{100}\right)\right.}{\mathrm{w}_{\mathrm{i}}} \times 100
$$

Where, $w_{i}$ is the initial weight of samples $(g), w_{f}$ is the final weight of samples at time $\mathrm{t}(\mathrm{g}), \mathrm{X}_{\mathrm{i}}$ is the initial moisture (w.b.) and $\mathrm{X}_{\mathrm{f}}$ is the final moisture content at time $\mathrm{t}$ (w.b.).

\section{Determination of colour difference $(\Delta E)$}

The colour of carrot samples was measured using Miniscan XE plus Hunter Lab Colourimeter (USA, Model 45/0-L). The colourimeter was calibrated using white plates given by the manufacturers. After that, the colour of all samples was examined in terms of ' $L$ ', ' $a$ ', and 'b' after preparing a paste of the fresh and dehydrated sample. The obtained values were recorded and compared with the values of fresh carrot sample. The colour difference $(\Delta \mathrm{E})$ was calculated by the equation 3, given by Alam et al., (2010).

$$
\Delta \mathrm{E}=\sqrt{\left[\left(\mathrm{L}-\mathrm{L}_{\mathrm{o}}\right)^{2}+\left(\mathrm{a}-\mathrm{a}_{\mathrm{o}}\right)^{2}+\left(\mathrm{b}-\mathrm{b}_{\mathrm{o}}\right)^{2}\right]}
$$

Where, $\mathrm{L}_{0}, \mathrm{a}_{0}$, and $\mathrm{b}_{0}$ represent the readings of fresh carrot sample. Therefore, the measured values of $L_{0}, a_{0}$, and $b_{o}$ for fresh carrot samples were 54.72, 28.01, and 37.1 , respectively.

\section{Experimental design}

The variables chosen for PVOD experiments were temperature (A), sugar concentration (B), salt concentration (C), and time (D). The variable levels were selected based on the previous studies described by several authors (Telis $\boldsymbol{e t}$ al. 2004; Jokić et al., 2007; Singh et al., 2007). A sequential design was performed according to a central composite rotatable design (CCRD) with the aid of the software Design Expert, version 7.0.3 (Stat Ease Inc., Minneapolis, MN, 2007) The levels of the variable in coded form and actual units are presented in Table 1.
Table 1 Independent process variables and coded levels used for experimental design

\begin{tabular}{lcccccc}
\hline \multirow{2}{*}{ Variable } & Name and Units & \multicolumn{5}{c}{ Levels } \\
\cline { 2 - 7 } & $\mathbf{- 2}$ & $\mathbf{- 1}$ & $\mathbf{0}$ & $\mathbf{1}$ & $\mathbf{2}$ \\
\hline $\mathrm{A}$ & $\begin{array}{c}\text { Temperature }\left({ }^{\circ} \mathrm{C}\right) \\
\text { Sugar }\end{array}$ & 35 & 40 & 45 & 50 & 55 \\
$\mathrm{~B}$ & $\begin{array}{c}\text { concentration } \\
\left({ }^{\circ} \text { Brix } / \%\right)\end{array}$ & 40 & 42.5 & 45 & 47.5 & 50 \\
& $\quad \begin{array}{c}\text { Salt } \\
\text { C }\end{array}$ & 5 & 7.5 & 10 & 12.5 & 15 \\
D & $\begin{array}{c}\text { concentration }(\%) \\
\text { Time (min) }\end{array}$ & 10 & 67.5 & 125.0 & 182.5 & 240 \\
\hline
\end{tabular}

The center points in the CCRD design were repeated in six times to estimate the reproducibility of the method. The experimental design of independent variables in uncoded forms and values of various responses are given in Table 2.

\section{Statistical data analysis}

Response surface methodology (RSM) was used to determine the relative contributions of $\mathrm{A}, \mathrm{B}, \mathrm{C}$ and $\mathrm{D}$ to various responses under study such as water loss (WL), solute gain (SG) and colour difference $(\Delta E)$ of osmotically dehydrated samples. The second-order polynomial (SOP) model was fitted to each of the response variables $\left(\mathrm{Y}_{\mathrm{k}}\right)$, as mentioned in equation 4 :

$\mathrm{Y}_{\mathrm{k}}=\mathrm{b}_{\mathrm{k} 0}+\sum_{\mathrm{i}=1}^{\mathrm{n}} \mathrm{b}_{\mathrm{ki}} \mathrm{X}_{\mathrm{i}}+\sum_{\mathrm{i}=1}^{\mathrm{n}} \mathrm{b}_{\mathrm{kii}} \mathrm{X}_{\mathrm{i}}^{2}+\sum_{\mathrm{i}=1}^{\mathrm{n}-1} \sum_{\mathrm{j}=\mathrm{i}+1}^{\mathrm{n}} \mathrm{b}_{\mathrm{kij}} \mathrm{X}_{\mathrm{i}} \mathrm{X}_{\mathrm{j}}+\mathrm{e}_{\mathrm{k}}$

Where, $Y_{k}$ is the response variables and $x_{i}$ represent the coded independent variables ( $\mathrm{i}=\mathrm{A}, \mathrm{B}, \mathrm{C}$ and $\mathrm{D}) . \mathrm{b}_{\mathrm{k} 0}, \mathrm{~b}_{\mathrm{ki}}, \mathrm{b}_{\mathrm{kii}}$, and $\mathrm{b}_{\mathrm{kij}}$ expressed are the constant, linear, quadratic and interaction regression coefficients, respectively.

The statistical models and significance of the terms in the regression equation were tested by analysis of variance (ANOVA). The model adequacies were checked by using model analysis, lack-of-fit test, and R-Squared values $\left(\mathrm{R}^{2}\right.$ and adjusted $\mathrm{R}^{2}$ ) analysis as outlined by various researchers (Lee et al., 2000; Weng et al., 2001). The significant terms in the model were judged from the probability level $(p<5 \%)$ which was calculated from the data. Co-efficient of variance $(\mathrm{CV})$ is the relative dispersion of the experimental points from the model prediction. Three dimensional response surfaces were generated and the Design Expert software, version 7.0.3 ( Stat Ease Inc., Minneapolis, MN) was used for numerical optimization.

\section{Numerical optimization and validation of process conditions}

A numerical optimization technique was applied for simultaneous optimization of the responses. For this purpose, the desired goals for each independent variable and response were chosen, which applied to either independent variables or responses. For optimization, the goals for responses would have maximized minimized, target, within range and none. In addition, the independent factors were kept within the experimental domain. For finding a solution, the targets were associated into a comprehensive composite function, D (x), called the desirability function (Myers and Montgomery, 1996), which is defined as:

$\mathrm{D}(\mathrm{x})=\left(\mathrm{d}_{1} \times \mathrm{d}_{2} \times \ldots \ldots \times \mathrm{d}_{\mathrm{n}}\right)^{1 / \mathrm{n}}$

Where, $d_{1}, d_{2} \ldots d_{n}$ are responses and $n$ expressed as the total number of responses in the measure. The function $\mathrm{D}(\mathrm{x})$ considered as the desirable areas for each response $\left(\mathrm{d}_{\mathrm{i}}\right)$. The desirability is an objective function which varied from zero to one at the desired goal. The numerical optimization technique searched to a point that maximized the desirability function. To attain the validation of the predicted process conditions, triplicate experiments were conducted adopting the conditions determined by the optimization and compared the predicted values to the experimentally obtained values. 
Table 2 Central composite rotatable design (CCRD) with experimental values of various responses

\begin{tabular}{|c|c|c|c|c|c|c|c|}
\hline \multirow[t]{2}{*}{ Run } & \multicolumn{4}{|c|}{ Uncoded Process variables } & \multicolumn{3}{|c|}{ Responses } \\
\hline & $\begin{array}{l}\text { Temp. } \\
\left({ }^{\circ} \mathrm{C}\right)\end{array}$ & $\begin{array}{c}\text { Sugar conc. } \\
\left({ }^{\circ} \text { Brix } / \%\right)\end{array}$ & $\begin{array}{l}\text { Salt conc. } \\
(\%)\end{array}$ & Time (min) & $\begin{array}{c}\text { Water loss } \\
(\%)\end{array}$ & $\begin{array}{c}\text { Solute gain } \\
(\%)\end{array}$ & $\begin{array}{c}\text { Color } \\
\text { difference }(\Delta E)\end{array}$ \\
\hline 1 & 40 & 47.5 & 7.5 & 67.5 & 36.26 & 8.05 & 6.36 \\
\hline 2 & 50 & 47.5 & 7.5 & 67.5 & 41.28 & 11.52 & 5.95 \\
\hline 3 & 55 & 45.0 & 10.0 & 125.0 & 47.28 & 12.05 & 5.58 \\
\hline $4(\mathrm{C})$ & 45 & 45.0 & 10.0 & 125.0 & 45.15 & 10.91 & 4.09 \\
\hline $5(\mathrm{C})$ & 45 & 45.0 & 10.0 & 125.0 & 46.34 & 12.95 & 5.15 \\
\hline 6 & 45 & 45.0 & 10.0 & 10.0 & 29.82 & 5.10 & 3.97 \\
\hline 7 & 50 & 42.5 & 7.5 & 182.5 & 41.92 & 11.79 & 7.99 \\
\hline 8 & 40 & 42.5 & 12.5 & 67.5 & 31.03 & 10.58 & 8.90 \\
\hline $9(\mathrm{C})$ & 45 & 45.0 & 10.0 & 125.0 & 43.0 & 12.13 & 6.02 \\
\hline 10 & 50 & 47.5 & 12.5 & 182.5 & 43.49 & 16.21 & 6.52 \\
\hline 11 & 45 & 45.0 & 10.0 & 240.0 & 46.60 & 12.24 & 5.40 \\
\hline 12 & 40 & 47.5 & 12.5 & 182.5 & 51.41 & 12.02 & 6.14 \\
\hline 13 & 40 & 42.5 & 12.5 & 182.5 & 47.02 & 11.96 & 7.97 \\
\hline 14 & 40 & 47.5 & 7.5 & 182.5 & 51.56 & 11.37 & 6.43 \\
\hline 15 & 50 & 42.5 & 7.5 & 67.5 & 41.28 & 8.25 & 4.60 \\
\hline 16 & 40 & 47.5 & 12.5 & 67.5 & 39.75 & 6.95 & 7.44 \\
\hline 17 & 40 & 42.5 & 7.5 & 67.5 & 31.40 & 8.10 & 4.58 \\
\hline 18 & 45 & 45.0 & 15.0 & 125.0 & 46.31 & 10.40 & 5.14 \\
\hline 19 & 35 & 45.0 & 10.0 & 125.0 & 50.64 & 9.96 & 5.75 \\
\hline $20(\mathrm{C})$ & 45 & 45.0 & 10.0 & 125.0 & 46.04 & 11.62 & 5.27 \\
\hline 21 & 45 & 40.0 & 10.0 & 125.0 & 41.88 & 9.20 & 8.70 \\
\hline 22 & 50 & 42.5 & 12.5 & 182.5 & 41.81 & 11.98 & 5.80 \\
\hline 23 & 45 & 45.0 & 5.0 & 125.0 & 41.89 & 10.78 & 5.88 \\
\hline 24 & 45 & 50.0 & 10.0 & 125.0 & 49.57 & 11.59 & 8.44 \\
\hline 25 & 40 & 42.5 & 7.5 & 182.5 & 45.59 & 10.99 & 8.11 \\
\hline 26 & 50 & 47.5 & 12.5 & 67.5 & 43.82 & 10.94 & 5.44 \\
\hline $27(\mathrm{C})$ & 45 & 45.0 & 10.0 & 125.0 & 46.91 & 12.27 & 5.05 \\
\hline 28 & 50 & 47.5 & 7.5 & 182.5 & 45.70 & 16.10 & 7.18 \\
\hline $29(\mathrm{C})$ & 45 & 45.0 & 10.0 & 125.0 & 45.68 & 12.83 & 5.30 \\
\hline 30 & 50 & 42.5 & 12.5 & 67.5 & 41.54 & 12.51 & 6.34 \\
\hline
\end{tabular}

* $\mathrm{C}=$ Center point

\section{RESULTS AND DISCUSSION}

\section{Fitting models}

The design of experiments with levels of four independent variables and responses at each combination are analyzed and presented in Table 2 . The values of responses were studied in the average of two replications. The second order polynomial eq. (4) was fitted to the experimental values and tested for adequacies by analysis of variance (ANOVA) are given in Table 3. The low probability value of the model for all responses (WL, SG and colour difference) also explains that the models were significant at a $95 \%$ confidence level. The ANOVA showed that the Lack-of-fit test was non-significant $(p>0.05)$ for all responses and confirms the applicability of the statistical method used. The $\mathrm{R}^{2}$ values estimated by a least square technique for WL, SG and colour difference $(\Delta \mathrm{E})$ were 0.94 , 0.88 and 0.82 , respectively, which measured a good fit of the models to the data It also exhibits a good correlation between the actual values and predicted values as shown in Fig. 1 (A-C). The values of adjusted- $\mathrm{R}^{2}$ were $0.88,0.76$ and 0.67 for WL, SG, and colour difference, respectively found close to the coefficient of determination $\left(\mathrm{R}^{2}\right)$ and suggesting that non-significant terms were not included in the model. The coefficient of variation $(\mathrm{CV})$ is a measure of reproducibility of the model and shows the reliability of the experiments. A model can be regarded fairly reproducible if its $\mathrm{CV}$ is not greater than $10 \%$ (Shishir et al., 2016). The low variation in coefficient value for WL (4.39\%) and SG (10.0\%) depicted that the models of these responses were highly reliable while the higher variation in CV $(12.81 \%)$ was attained for colour difference.

$$
\begin{gathered}
\mathrm{WL}=45.09+1.96 \mathrm{~B}+3.99 \mathrm{D}-3.26 \mathrm{AD}-2.12 \mathrm{D}^{2} \\
\left(\mathrm{R}^{2}=0.88\right) \ldots \ldots \ldots \ldots \ldots \ldots(6)
\end{gathered}
$$

Where, $\mathrm{WL}=$ water loss $(\%), \mathrm{SG}=$ solute gain $(\%), \Delta \mathrm{E}=$ colour difference, $\mathrm{A}=$ temperature $\left({ }^{\circ} \mathrm{C}\right), \mathrm{B}=$ sugar concentration $\left({ }^{\circ} \mathrm{Brix} / \%\right), \mathrm{C}=$ salt concentration $(\%)$, and $\mathrm{D}=$ time (min).
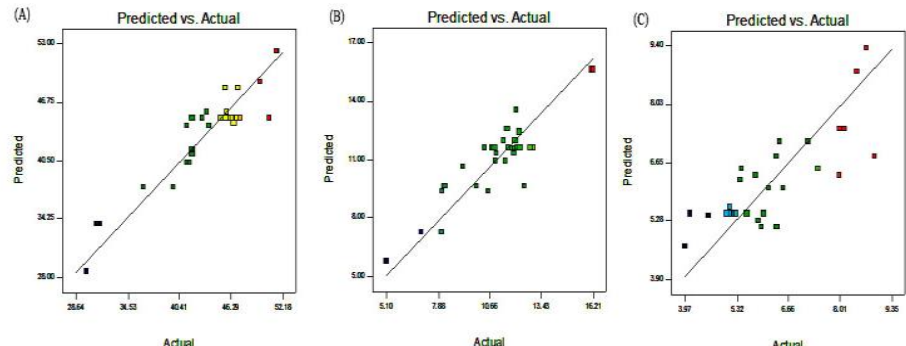

Figure 1 The fitted line plot signifying the closeness between actual values and predicted values for (A) water loss (WL) (B) solute gain (SG) and (C) colour difference $(\Delta \mathrm{E})$ 
Table 3 ANOVA showing the effects of the variables on water loss (WL), solute gain (SG) and colour difference ( $\Delta \mathrm{E})$ for PVOD of carrots

\begin{tabular}{|c|c|c|c|c|c|c|c|c|c|c|c|c|c|}
\hline \multirow[t]{2}{*}{ Source } & \multirow[t]{2}{*}{ DF } & & \multicolumn{3}{|c|}{ Water loss (WL) } & \multicolumn{4}{|c|}{ Solute gain (SG) } & \multicolumn{4}{|c|}{ Colour difference $(\Delta E)$} \\
\hline & & $\boldsymbol{\beta}$ & $\begin{array}{l}\text { Sum of } \\
\text { square }\end{array}$ & $\begin{array}{c}\text { Mean } \\
\text { Square }\end{array}$ & $p$-value & $\boldsymbol{\beta}$ & $\begin{array}{l}\text { Sum of } \\
\text { square }\end{array}$ & $\begin{array}{c}\text { Mean } \\
\text { Square }\end{array}$ & $p$-value & $\boldsymbol{\beta}$ & $\begin{array}{l}\text { Sum of } \\
\text { square }\end{array}$ & $\begin{array}{c}\text { Mean } \\
\text { Square }\end{array}$ & $p$-value \\
\hline Model & 14 & 45.09 & 827.87 & 59.13 & $0.0001^{*}$ & 11.61 & 134.68 & 9.62 & $0.0002^{*}$ & 5.45 & 34.01 & 6.80 & $0.0018^{*}$ \\
\hline Temp. (A) & 1 & $4.16 \mathrm{E}-3$ & 4.167E-4 & 4.17E-4 & 0.9916 & 0.98 & 22.93 & 22.93 & $0.0006^{*}$ & -0.27 & 1.55 & 1.73 & 0.1369 \\
\hline $\begin{array}{l}\text { Sugar Conc. } \\
\text { (B) }\end{array}$ & 1 & 1.96 & 92.28 & 92.28 & $0.0001^{*}$ & 0.49 & 5.78 & 5.78 & $0.0472^{*}$ & -0.14 & 0.47 & 0.47 & 0.4009 \\
\hline $\begin{array}{l}\text { Salt Conc. } \\
\text { (C) }\end{array}$ & 1 & 0.57 & 7.84 & 7.84 & 0.1619 & 0.26 & 1.61 & 1.61 & 0.2715 & 0.078 & 0.14 & 0.14 & 0.6364 \\
\hline Time (D) & 1 & 3.99 & 381.60 & 381.60 & $0.0001^{*}$ & 1.66 & 66.0 & 66.0 & $0.0001^{*}$ & 0.39 & 3.67 & 3.67 & $0.0285^{*}$ \\
\hline $\mathrm{AB}$ & 1 & -1.01 & 16.40 & 16.40 & 0.0504 & 0.84 & 11.36 & 11.36 & $0.0084^{*}$ & 0.22 & 0.78 & 0.78 & 0.2795 \\
\hline $\mathrm{AC}$ & 1 & -0.24 & 0.96 & 0.96 & 0.6142 & 0.061 & 0.060 & 0.060 & 0.8286 & -0.41 & 2.71 & 2.71 & 0.0548 \\
\hline $\mathrm{AD}$ & 1 & -3.26 & 169.91 & 169.91 & $0.0001^{*}$ & 0.013 & $2.5 \mathrm{E}-03$ & $2.5 \mathrm{E}-03$ & 0.9647 & 0.24 & 0.89 & 0.89 & 0.2495 \\
\hline $\mathrm{BC}$ & 1 & 0.15 & 0.38 & 0.38 & 0.7511 & -0.55 & 4.86 & 4.86 & 0.0660 & -0.26 & 1.05 & 1.05 & 0.2136 \\
\hline $\mathrm{BD}$ & 1 & $-2.5 E-3$ & $1.0 \mathrm{E}-04$ & $1.0 \mathrm{E}-4$ & 0.9959 & 0.69 & 7.51 & 7.51 & $0.0263^{*}$ & -0.27 & 1.19 & 1.19 & 0.1874 \\
\hline $\mathrm{CD}$ & 1 & -0.43 & 3.03 & 3.03 & 0.3751 & -0.2 & 0.62 & 0.62 & 0.4911 & -0.62 & 6.14 & 6.14 & $0.0062^{*}$ \\
\hline $\mathrm{A}^{2}$ & 1 & 0.52 & 7.27 & 7.27 & 0.1769 & -0.1 & 0.30 & 0.30 & 0.6295 & 0.21 & 1.04 & 1.04 & 0.2174 \\
\hline $\mathrm{B}^{2}$ & 1 & -0.29 & 2.37 & 2.37 & 0.4316 & -0.26 & 1.81 & 1.81 & 0.2447 & 0.90 & 24.40 & 24.40 & $0.0001^{*}$ \\
\hline $\mathrm{C}^{2}$ & 1 & -0.7 & 13.44 & 13.44 & 0.0733 & -0.21 & 1.19 & 1.19 & 0.3421 & 0.17 & 0.87 & 0.87 & 0.2563 \\
\hline $\mathrm{D}^{2}$ & 1 & -2.12 & 129.46 & 129.46 & $0.0001^{*}$ & -0.62 & 13.0 & 13.0 & $0.0055^{*}$ & -0.03 & 0.022 & 0.022 & 0.8553 \\
\hline Lack of fit & 10 & & 44.96 & 4.50 & $0.1737^{* *}$ & & 15.62 & 1.56 & $0.1453^{* *}$ & & 7.46 & 0.75 & $0.2416^{* *}$ \\
\hline $\mathrm{R}^{2}$ & & 0.94 & & & & 0.88 & & & & 0.82 & & & \\
\hline Adjusted- $\mathrm{R}^{2}$ & & 0.88 & & & & 0.76 & & & & 0.67 & & & \\
\hline C.V. $\%$ & & 4.39 & & & & 10.0 & & & & 12.81 & & & \\
\hline Std. dev. & & 1.90 & & & & 1.11 & & & & 0.78 & & & \\
\hline
\end{tabular}

* Significant at $5 \%$ level of significance $(p<0.05) ; \beta=$ coefficient of estimate; $\mathrm{DF}=$ Degree of freedom

$* *$ Non-significant at $95 \%$ confidence level $(p>0.05)$

Influence of process variables on the responses

The main and interactive effect of different independent variables such as temperature (A), sugar concentration (B), salt concentration (C) and restoration time at atmospheric pressure (D) were observed on the responses. Following sections describe in details about the influences of these independent variables on the responses.

\section{Effect on water loss (WL)}

The results of water loss (WL) of PVOD of carrot slices are presented in Table 2. The WL during PVOD of carrot slices was ranged from 29.82 to $51.56 \%$. The process parameters, sugar concentration and time restored at atmospheric pressure have the positive and significant effect on water loss $(p<0.05)$. For water loss, the magnitude of $\beta$ value (Table 3 ) shows that the restoration time at atmospheric pressure after vacuum pulse application has the maximum positive effect on water loss followed by sugar concentration. The positive signs of linear independent variables revealed that water loss increased with the increase of restoration time and sugar concentration. Similar trends for water loss were reported by Lewicki and Lukaszuk (2000) for apple, Azoubel and Murr (2004), and An et al. (2013) for cherry tomatoes. Water loss increased with an increase in the sugar concentration since the solute concentration gradient increased between the solution and the food, with the consequent increase in pressure (Chafer et al., 2003; Viana et al., 2014). In addition, the ternary solution of different concentrations was used during PVOD of carrot slices which contains salt may increase the driving force of the process for the reduction in water content thus leading to the increase in WL (Hamledari et al., 2012) However, the quadratic square terms of the time restored at atmospheric pressure $\left(D^{2}\right)$ has the significant and negative effect on WL, whereas the quadratic terms of other independent variables were non-significant at $p<0.05$ (Table 3 ).

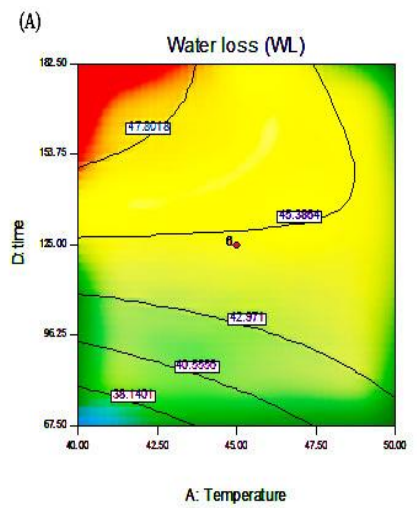

(B)

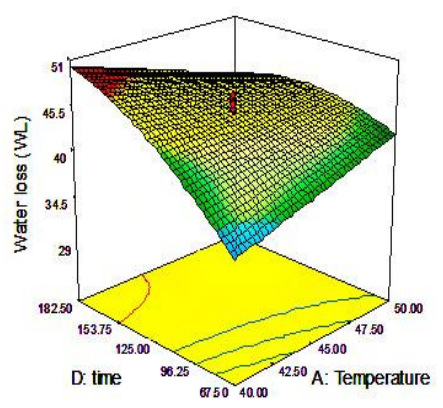

Figure 2 Response surface plots showing the effects of process parameters on water loss (WL); (A) 2D contour plot (B) 3D contour plot in relation to solution temperature and time restored at atmospheric pressure

To visualize the combined effect of different independent variables on WL response surface $2 \mathrm{D}$ and $3 \mathrm{D}$ contour plots were generated for the fitted model as shown in Fig. 2 (A-B). Only the interaction term of solution temperature and process time restored at atmospheric pressure (AD) has the significant influence on WL (Table 3) at the $95 \%$ confidence level. Increase in time restored at atmospheric pressure (125-182.5 min) with a combination solution temperature $\left(47.5-50^{\circ} \mathrm{C}\right)$ resulted in the reduction of water loss. This result was corroborated with the findings of Ito et al. (2007), Corrêa et al. (2010) and Ferrari et al. (2011) for mango slices, guavas and melon, respectively. The samples showed greater water loss from the vegetable tissues during first 120 min when restored at atmospheric pressure is because of the application of vacuum conditions. After that, a gradual stabilization of WL was observed at the end of the osmotic process. The increase of WL during the first period restored at atmospheric pressure can be explained by the hydrodynamic mechanism that was applied at the beginning of the process. With the application of pulsed vacuum conditions, the occluded gas in the intercellular spaces of the food tissues are removed and when restored at atmospheric pressure, the pores of the food material are filled by the osmotic solution since making the mass transfer easier (Deng and Zhao, 2008; Medina-Torres et al., 2008; Mundada et al., 2010). Increasing temperature above $47^{\circ} \mathrm{C}$ caused decreasing in the carrot samples WL. This can be related to the shorter vacuum pulse time which released the internal gas partially presence in the food spores. Hence, when the viscosity of the osmotic solution reduces as the temperature raises resultant in lessening water and mass loss because of the lack of free volume for impregnation (Torres et al., 2007). 
Table 2 showed that solute gain (SG) ranges from 5.10 to $16.21 \%$. The $p$ and $\beta$ values in Table 3 revealed that the independent process variable of temperature, sugar concentration and osmosis time restored at atmospheric pressure exhibited the positive and significant effect on SG at a 5\% level of significance. The relative magnitude of $\beta$ value illustrates that the osmotic restoration time at atmospheric pressure was the most significant factor on the solute gain followed by solution temperature and sugar concentration on SG (Table 3). These results are under the findings observed by Ferrari and Hubinger (2008), Sutar and Prasad (2011) and Zapata et al. (2016) in melon cubes, carrots and cape gooseberry, respectively. This outcome revealed that SG increased with the increase of restoration time at atmospheric pressure after the vacuum pulse conditions were applied. The higher the gain in the solute is because of the application of vacuum pulse at the first minutes of the process which provoke the opening of food pores and the exit of entrapped air. Since, when restored at atmospheric pressure for further osmotic dehydration (OD) for the greater time, such pores are filled with the osmotic solution thus may affect the foods to solute gain (Huayamave and Cornejo, 2005; Zapata et al., 2016). However, only the quadratic square terms of time has the negative and significant effect $(p<0.05)$ on SG while other process variables has the non-significant effect on solute gain. The negative coefficient of the quadratic term of time suggested that an excessive increase in the levels of this variable resultant in the significant decrease in SG.

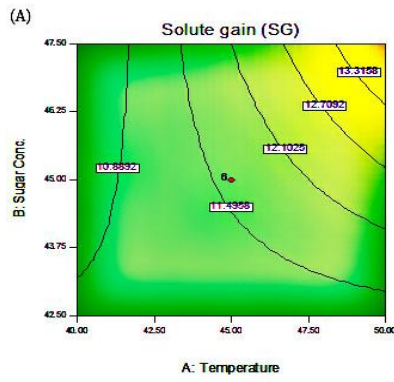

(c)

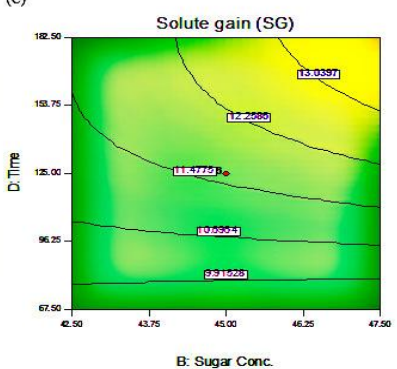

(B)
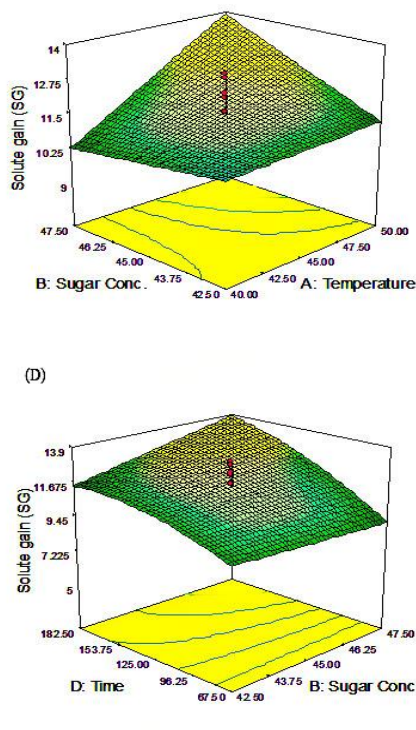

Figure 3 Response surface plots showing the effects of process parameters on solute gain (SG); (A-B) 2D and 3D contour plots in relation to solution temperature and sugar concentration; (C-D) 2D and 3D contour plots in relation to sugar concentration and restoration time at atmospheric pressure

To get the better understanding of the variables and their interactions on SG, the response surface contour plots are depicted in Fig. 3 (A-D) for SG during PVOD of carrots. The interaction effect of solution temperature and sugar concentration (AB) was the positive and statistically significant effect on SG at the 5\% level of significance. The results showed that the SG increased with the increasing solution temperature from 40 to $50^{\circ} \mathrm{C}$ and sugar concentration from 42.5 to $47.5^{\circ}$ Brix (Fig. 3A-B). The higher solution temperature favors the swelling and plasticization of the cell membrane, which make the food tissues easier to transfer water and entrance of solids. The viscosity of the osmotic solution also decreased with an increase in solution temperature resulting lower external resistance to mass transfer (Uddin et al., 2004; Lombard et al., 2008). However, the increase in osmotic solution concentration also contributed to the less increase in solute gain while used a ternary solution of sugar-salt regarding to a binary solution of sodium chloride. The greater size of sugar molecules in comparison with that of salt molecules could hinder their entering the cells thus lowering in the solute uptake (Heredia et al., 2007; Ferrari et al., 2011; Corrêa et al., 2016). The interaction between sugar concentration and time restored at atmospheric pressure (BD) was significant at the 95\% confidence level. The findings showed that the sugar concentration was more effective for SG at higher restoration time of $182.50 \mathrm{~min}$ for atmospheric pressure osmotic process (Fig. $3 \mathrm{C}$-D). This could be attributed to the rupture of cell wall above $150 \mathrm{~min}$ resulting in higher solid incorporation. The PVOD process is accompanied with the hydrodynamic mechanism (HDM) which deformed food matrix by the expansion and compression of the gas occluded into the food porous structure. Therefore, it alters the cell wall resistance and influences the final solid uptake throughout osmotic process (Fito et al., 1996; Castelló et al., 2010).
The colour differences $(\Delta \mathrm{E})$ of carrot slices ranged from 3.97 to 8.90 (Table 2), which illustrated that the colour differences between lowest and highest value was $76.61 \%$ after PVOD of the carrot slices at different experimental conditions. The co-efficient of estimate $\beta$ values indicated that the time $(\beta=0.39)$ restored at atmospheric pressure has a positive effects on the colour parameters whereas other linear process variables have no significant effects at the 5\% level of significance (Table 3). It implies that with the increase of restoration time leads to the colour degradation of the dehydrated product. Similar behavior of changes in colour parameters were also reported by Singh et al. (2010), Moreira et al. (2011) and Najafi et al. (2014) for carrots, chestnuts and red pitaya, respectively. The carrot contains a high content of carotenoid pigments in which $\beta$-carotene present usually. This $\beta$-carotene may be oxidized with the increase of process time and lower water activity, thus may cause in carotene bleaching which contributes to changes or losses of the colour of osmotically dehydrated carrot slices (Kidmose et al., 2002). However, the quadratic square terms of sugar concentration has the significant effects while other variables have no effects on colour difference $(p<0.05)$.

The $2 \mathrm{D}$ and $3 \mathrm{D}$ contour response surface plots are generated for the fitted model by keeping two other independent variables at the center points to visualize the combined effect on colour difference (Fig 4A-B). The interaction of the "salt concentration and time" has the negative and significant effect on the colour parameters (Table 3 ) at the $95 \%$ confidence level. The combination of a fall-off process time (125 to $67.50 \mathrm{~min}$ ) at atmospheric pressure and with the salt concentration ranged from 7.50 to $10 \%$ in ternary solutions, thus may cause a lowering in the colour differences of the dehydrated product (Fig. 4A-B). In some vegetables such as carrots, accumulating high amounts of carotenoids in its roots are mainly prevailed by carotene pigments, which are combined with the carbon and hydrogen atoms resulting in low polar compounds. These carotene pigments of vegetables are degraded because of the oxidative browning reactions, these reactions can be limited by hindering the access of oxygen into the intercellular spaces through the application of vacuum conditions. With the vacuum pulse application, the entrapped gases occluded in the intercellular spaces of the food tissues are removed and the food spores are filled by the osmotic solution. Hence, it may reduce the availability of oxygen for oxidative reactions during PVOD and for shorter osmosis time at atmospheric pressure. So, it appears to less increase in colour difference of the dehydrated product (Talens et al., 2002; Chafer et al., 2003). Apart from this, an increasing in salt concentration over $12.50 \%$ in the ternary osmotic solutions with the increase of time suggesting that the difference in the colour parameters was decreased more than the fresh sample (Fig. 4AB). The chromoplasts in a carrot root contain mainly large carotenoid crystals which deposited in the plant plastids. These carotenoids containing plastids are hydrophobic and degraded easily from the food matrix during dehydration and biosynthesis of that plastids may provoke the over formation of carotenoid pigments. Since, the addition of salts in ternary osmotic solution may reduce the rate of degradation of plastids, which neutralizes the negative polar surface charge of lipids and protein of plastids by the positive ions of salts (Schweiggert et al., 2012; Viana et al., 2014). Therefore, the colour parameters of the dehydrated sample were decreased to a lesser extent than the fresh sample.
(A)

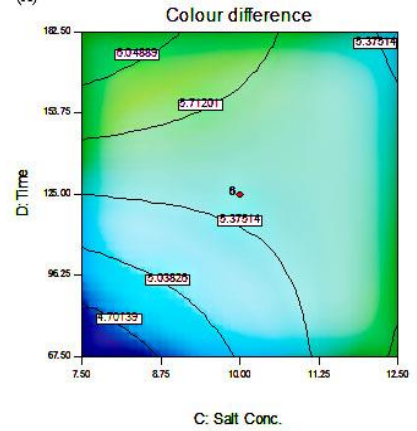

(B)

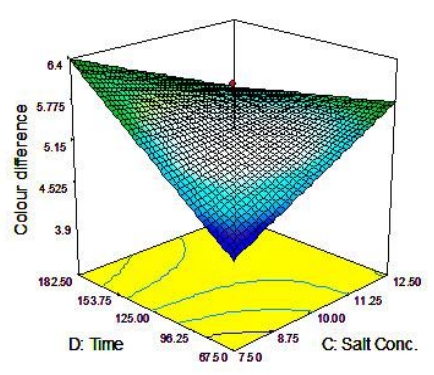

Figure 4 Response surface plots showing the effects of process parameters on colour difference $(\Delta \mathrm{E})$; (A) 2D contour plot (B) 3D contour plot in relation to salt concentration and time restored at atmospheric pressure

\section{Optimization of the process variables by the desirability function approach}

The numerical optimization of the pulsed vacuum osmotic dehydration (PVOD) of carrot slices was performed using the desirability function technique for the developed models. The main criteria for constraints were to maximize WL, and minimize SG and colour difference of the dehydrated product. However, the independent variables such as temperature, sugar concentration, salt concentration and time restored at atmospheric pressure were set in the experimental range for the optimization of the process variables. The optimized values of solution temperature, sugar concentration, salt concentration and 
restoration time found were $50^{\circ} \mathrm{C}, 45.47^{\circ} \mathrm{Brix}, 7.50 \%$ and $67.50 \mathrm{~min}$ respectively. Therefore, the predicted water loss, solute gain, and colour difference values attributed under these optimum conditions were $42.61 \%$, $10.42 \%$ and 4.38 , respectively.

Table 4 Predicted and experimental values of the responses at optimum conditions for pulsed vacuum osmotic dehydration (PVOD) of carrot slices

$$
\text { Response }
$$

Water Loss (\%)
Solute gain (\%)
Colour difference

$(\Delta \mathrm{E})$ Predicted value Experimental \pm SEM

$10.51 \pm 0.18$

$4.96 \pm 0.26$ $\overline{* \mathrm{SEM}}=\overline{\text { Standard error of the mean }}$

\section{Validation of the models}

The optimized results were validated by conducting triplicate experiments under the recommended optimum condition with a slight alteration in sugar concentration by $45^{\circ}$ Brix and restoration time by $68 \mathrm{~min}$ in substitution of $45.47^{\circ} \mathrm{Brix}$ and $67.50 \mathrm{~min}$. The predicted values of respective responses and experimental values are shown in Table 4 . The experimental values were found decent with the predicted values which satisfy the predicted response surface model.

\section{CONCLUSIONS}

Response surface methodology (RSM) showed that the models obtained were suitable to describe the experimental data of water loss (WL), solute gain (SG) and colour difference $(\Delta \mathrm{E})$. The process time restored at atmospheric pressure has the most pronounced effect on the mass transfer parameters and the colour parameters of the osmotically dehydrated carrot slices $(p<0.05)$. The mass transfer rates were improved due to the expulsion of occludes gases during PVOD of carrot slices, which induces the exchange of the water and solute in the food matrix. The degradation of colour parameters of the dehydrated samples was increased with the increase of the dehydration time. The long duration of the OD could be resulted in the deteriorating of the carotenoid pigments for oxidative browning reactions. For the fitted models, the optimum conditions were found to be $50^{\circ} \mathrm{C}, 45.47^{\circ} \mathrm{Brix}, 7.50 \%$ and $67.50 \mathrm{~min}$ of solution temperature, sugar concentration, salt concentration and osmosis time at atmospheric pressure, respectively. The various experimental response values were found closeness to the predicted values. The process variables of PVOD process could be optimized by using RSM that shorten the number of experimental runs. Therefore, PVOD pretreatment could remove a large portion of moisture at low temperature. This may shorten the total time of final drying, which in turns reduce the loss of the thermal sensitive nutrition and sensory quality.

\section{REFERENCES}

ALAM, M. S., AMARJIT, S., SAWHNEY, B. K. 2010. Response surface optimization of osmotic dehydration process for aonla slices. Journal of Food Science and Technology, 47(1), 47-54. https://doi.org/10.1007/s13197-0100014-4

AN, K., LI, H., ZHAO, D., DING, S., TAO, H., WANG, Z. 2013. Effect of Osmotic Dehydration with Pulsed Vacuum on Hot-Air Drying Kinetics and Quality Attributes of Cherry Tomatoes. Drying Technology, 31(6),698-706. https://doi.org/10.1080/07373937.2012.755192

AOAC. 2005. Official methods of analysis of AOAC International. Arlington, Va: AOAC International.

AZOUBEL, P. M., MURR, F.E.X. 2004. Mass transfer kinetics of osmotic dehydration of cherry tomato. Journal of Food Engineering, 61(3), 291-295. https://doi.org/10.1016/S0260-8774(03)00132-8

CASTELLÓ, M. L., FITO, P. J., CHIRALT, A. 2010. Changes in respiration rate and physical properties of strawberries due to osmotic dehydration and storage. Journal of Food Engineering, 97(1), 64-71. https://doi.org/10.1016/j.jfoodeng.2009.09.016

CHAFER, M., GONZALEZ-MARTINEZ, C. FERNANDEZ, B., PEREZ, L., CHIRALT, A. 2003. Effect of blanching and vacuum pulse application on osmotic dehydration of pear. Food Science and Technology International, 9(5),321-328. https://doi.org/10.1177/1082013203039253

CORRÊA, J. L. G., VIANA, A. D., MENDONÇA, K. S., JUSTUS, A. 2016. Optimization of Pulsed Vacuum Osmotic Dehydration of Sliced Tomato. In: Delgado J., Barbosa de Lima A. (eds), Drying and Energy Technologies (Vol. 63:207-228). Switzerland:Springer International Publishing. https://doi.org/10.1007/978-3-319-19767-8_11

CORRÊA, J. L. G., PEREIRA, L. M., VIEIRA, G. S., HUBINGER, M. D. 2010. Mass transfer kinetics of pulsed vacuum osmotic dehydration of guavas. Journal of Food Engineering, 96(4), 498-504. https://doi.org/10.1016/j.jfoodeng.2009.08.032
CORRÊA, J. L. G., ERNESTO, D. B., de MENDONÇA, K. S. 2016. Pulsed vacuum osmotic dehydration of tomatoes: sodium incorporation reduction and kinetics modeling. LWT - Food Science and Technology, 71, 17-24. https://doi.org/10.1016/j.lwt.2016.01.046

DENG, Y., ZHAO, Y. 2008. Effects of pulsed-vacuum and ultrasound on the osmodehydration kinetics and microstructure of apples (Fuji). Journal of Food Engineering, 85(1), 84-93. https://doi.org/10.1016/j.jfoodeng.2007.07.016

EL-AOUAR, Â. A., AZOUBEL, P. M., BARBOSA, J. L., MURR, F. E. X. 2006 Influence of the osmotic agent on the osmotic dehydration of papaya (Carica papaya L.). Journal of Food Engineering, 75(2), 267-274 https://doi.org/10.1016/j.jfoodeng.2005.04.016

FANTE, C., CORRÊA, J., NATIVIDADE, M., LIMA, J., LIMA, L. 2011. Drying of plums (Prunus sp, c.v Gulfblaze) treated with $\mathrm{KCl}$ in the field and subjected to pulsed vacuum osmotic dehydration. Internation Journal of Food Science and Technology, 46(5), 1080-1085. https://doi.org/10.1111/j.13652621.2011.02619.x

FERRARI, C.C., ARBALlO, J.R., MASCHERONI, R.H., HUBINGER, M. D. 2011. Modelling of mass transfer and texture evaluation during osmotic dehydration of melon under vacuum. International Journal of Food Science and Technology, 46(2), 436-443. https://doi.org/10.1111/j.1365-2621.2010.02510.x FERRARI,C.C., HUBINGER, M. D. 2008. Evaluation of the mechanical properties and diffusion coefficients of osmodehydrated melon cubes. International Journal of Food Science and Technology, 43(11), 2065-2074. https://doi.org/10.1111/j.1365-2621.2008.01824.x

FITO, P., ANDRÉS, A., CHIRALT, A., PARDO, P. 1996. Coupling of hydrodynamic mechanism and deformation-relaxation phenomena during vacuum treatments in solid porous food-liquid systems. Journal of Food Engineering, 27(3), 229-240. https://doi.org/10.1016/0260-8774(95)00005-4 GIRI, S.K., PARASAD, S. 2007. Optimization of microwave-vacuum drying of button mushrooms using response surface methodology. Drying Technology, 25(5), 901-911. https://doi.org/10.1080/07373930701370407

HAMLEDARI, A., BASSIRI, A., GHIASSI T. B., BAMENI. M. M. 2012. Pulsed vacuum osmotic dehydration of garlic bulbs followed by microwave drying. Journal of Food Biosciences and Technology, 2(2), 41-56.

HEREDIA, A., BARRERA, C., ANDRE, A. 2007. Drying of cherry tomato by a combination of different dehydration techniques. Comparison of kinetics and other related properties. Journal of Food Engineering, 80(1),111-118. https://doi.org/10.1016/j.jfoodeng.2006.04.056

HUAYAMAVE, E.C., CORNEJO, F. 2005. Influence of vacuum pressures on mass transfer during osmotic dehydration of mango. Revista Tecnológica ESPOL, 18(1), 141-145.

ITO, A. P., TONON, R. V., PARK, K. J., HUBINGER, M. D. 2007. Influence of process conditions on the mass transfer kinetics of pulsed vacuum osmotically dehydrated mango slices. Drying Technology, 25(10), 1769-1777. https://doi.org/10.1080/07373930701593263

JOKIĆ, A., GYURA, J., LEVIĆ, L., ZAVARGÓ, Z. 2007. Osmotic dehydration of sugar beet in combined aqueous solutions of sucrose and sodium chloride. Journal of Food Engineering, 78(1), 47-51. https://doi.org/10.1016/j.jfoodeng.2005.09.003

KARIM, M. A., HAWLADER, M. N. A. 2005. Mathematical modelling and experimental investigation of tropical fruits drying. International Journal of Heat and Mass Transfer, 48(23-24), 4914-4925. https://doi.org/10.1016/j.ijheatmasstransfer.2005.04.035

KIDMOSE, U., EDELENBOS,M., NØRBÆK, R., CHRISTENSEN, L. P. 2002. Colour stability in vegetables. In D. B. MacDougall (Ed.), Colour in food: Improving quality (pp. 179-232). CRC Press Publishing Limited, Cambridge. http://dx.doi.org/10.1533/9781855736672.2.179

KUMAR, C., KARIM, M. A., JOARDDER, M. U. H. 2014. Intermittent drying of food products: a critical review. Journal of Food Engineering, 121(1), 48-57. https://doi.org/10.1016/j.jfoodeng.2013.08.014

LEE, J., YE, L., LANDEN, W. O., EITENMILLER, R. R. 2000. Optimization of an extraction procedure for the quantification of vitamin e in tomato and broccoli using response surface methodology. Journal of Food Composition and Analysis, 13(1), 45-57. https://doi.org/10.1006/jfca.1999.0845

LENART, A. 1996. Osmo-convective drying of fruits and vegetables: technology and application. Drying Technology, 14(2), 391-413. https://doi.org/10.1080/07373939608917104

LEWICKI, P. P., LUKASZUK, A. 2000. Effect of osmotic dewatering on rheological properties of apple subjected to convective drying. Journal of Food Engineering, 45(3), 119-126. https://doi.org/10.1016/S0260-8774(00)00025-X

LOMBARD, G. E., OLIVEIRA, J. C., FITO, P., ANDRÉS, A. 2008. Osmotic dehydration of pineapple as a pre-treatment for further drying. Journal of Food Engineering, 85(2), 277-284. https://doi.org/10.1016/j.jfoodeng.2007.07.009 MEDINA-TORRES, L.,GALLEGOS-INFANTE, J. A.,GONZALEZ-LAREDO, R. F., ROCHA-GUZMAN, N. E. 2008. Drying kinetics of nopal (Opuntia ficusindica) using three different methods and their effect on their mechanical properties. LWT - Food Science and Technology, 41(7), 1183-1188. https://doi.org/10.1016/j.1wt.2007.07.016

MOREIRA, R., CHENLO, F., CHAGURI, L., VÁZQUEZ, G. 2011. Air drying and colour characteristics of chestnuts pre-submitted to osmotic dehydration with 
sodium chloride. Food and Bioproducts Processing, 89(2), 109-115. https://doi.org/10.1016/j.fbp.2010.03.013

MUNDADA, M., SINGH, B.,MASKE, S. 2010. Optimisation of processing variables affecting the osmotic dehydration of pomegranate arils. International Journal of Food Science \& Technology, 45(8), 17321738. https://doi.org/10.1111/j.1365-2621.2010.02328.X

MYERS, R. H., MONTGOMERY, D. C.1995. Response Surface Methodology: Process and Product in Optimization Using Designed Experiments $\left(2^{\text {nd }}\right.$ ed.). Wiley, New York. https://doi.org/10.1201/9780203740774

NAJAFI, A.H., YUSOF, Y.A., RAHMAN, R.A., GANJLOO, A., LING, C.N. 2014. Effect of osmotic dehydration process using sucrose solution at mild temperature on mass transfer and quality attributes of red pitaya (Hylocereus polyrhizusis). International Food Research Journal, 21(2), 625-630.

NIJHUIS, H. H., TORRINGA, H. M., MURESAN, S., YUKSEL, D., LEGUIJT C., KLOEK, W. 1998. Approaches to improving the quality of dried fruit and vegetables. Trends in Food Science \& Technology, 9(1), 13-20. https://doi.org/10.1016/S0924-2244(97)00007-1

ORSAT, V., CHANGRUE, V., RAGHAVAN, G.S.V.2006. Microwave drying of fruits and vegetables. Stewart Postharvest Review, 2(6), 49. http://dx.doi.org/10.2212/spr.2006.6.4

RASTOGI, N. K., RAGHAVARAO, K. S. M. S. 1997. Water and solute diffusion coefficients of carrot as a function of temperature and concentration during osmotic dehydration. Journal of Food Engineering, 34(4), 429-440. https://doi.org/10.1016/S0260-8774(98)80034-4

Gandolfi, O. R. R., Goncalves, G. R. F., Bonomo, R.C.F., Fontan, R. da C. I 2018. Sorption equilibrium and kinetics of thin-layer drying of green bell peppers. Emirates Journal of Food and Agriculture, 30(2):137-143. https://doi.org/10.9755/ejfa.2018.v30.i2.1606

SHISHIR, M. R. I., TAIP, F. S., AZIZ, N. A., TALIB, R. A., SARKER, M. S. H 2016. Optimization of spray drying parameters for pink guava powder using RSM. Food Science and Biotechnology Journal, 25(2): 461-468 https://doi.org/10.1007/s10068-016-0064-0

SAGAR, V. R., KUMAR, S. P. 2010. Recent advances in drying and dehydration of fruits and vegetables: A review. http://dx.doi.org/10.1007/s13197-010-0010-8 SCHWEIGGERT, R.M.,MEZGER,D., SCHIMPF,F.,STEINGASS, C.B. CARLE, R. 2012. Influence of chromoplast morphology on carotenoid bioaccessibility of carrot, mango, papaya, and tomato. Food Chemistry, 135(4),2736-2742. https://doi.org/10.1016/j.foodchem.2012.07.035

SHETE, Y. V., CHAVAN, S. M., CHAMPAWAT, P. S., JAIN S. K. (2018). Reviews on osmotic dehydration of fruits and vegetables. Journal of Pharmacognosy and Phytochemistry, 7(2), 1964-1969.

SHI, J., LE MAGUER, M. 2002. Osmotic dehydration of foods: mass transfer and modeling aspects. Food Reviews International, 18(4), 305-335. https://doi.org/10.1081/FRI-120016208

REZAUL, M. S. I., KARIM, N., BAO, T., GOWD, V., DING, T., SUN, C. CHEN, W. (2019). Cold plasma pretreatment-A novel approach to improve the hot air drying characteristics, kinetic parameters and nutritional attributes of shiitake mushroom. Drying Technology, 1-17. https://doi.org/10.1080/07373937.2019.1683860

SINGH, B., KUMAR, A., GUPTA, A. K. 2007. Study of mass transfer kinetics and effective diffusivity during osmotic dehydration of carrot cubes. Journal of $\begin{array}{llll}\text { Food } \quad \text { Engineering, } & \text { 79(2), 471-480 }\end{array}$ https://doi.org/10.1016/j.jfoodeng.2006.01.074

SINGH, B., PANESAR, P. S.,NANDA, V. 2008. Optimization of osmotic dehydration process of carrot cubes in sucrose solution. Journal of Food Process Engineering, 31(1), 1-20. https://doi.org/10.1016/j.foodchem.2010.04.075

SINGH, B., PANESAR, P. S., NANDA, V., KENNEDY, J. F. 2010. Optimisation of osmotic dehydration process of carrot cubes in mixtures of sucrose and sodium chloride solutions. Food Chemistry, 123(3), 590-600. https://doi.org/10.1016/j.foodchem.2010.04.075

Singh, R., Giri, S. K., Kotwaliwale, N. 2014. Shelf-life enhancement of green bell pepper (Capsicum апnиит L.) under active modified atmosphere storage. Food Packaging and Shelf Life, 1(2), 101-112. https://doi.org/10.1016/j.fps1.2014.03.001

Stat-Ease, I. (2007). Design Expert Software, Educational Version 7.0.3. Wiley Publishing.

SUTAR, P. P., PRASAD, S. 2011. Optimization of osmotic dehydration of carrots under atmospheric and pulsed microwave vacuum conditions. Drying Technology, 29(3), 371-380. https://doi.org/10.1080/07373937.2010.497955

TALENS, P., MARTÍNEZ-NAVARRETE, N., FITO, P., CHIRALT, A. 2002. Changes in optical and mechanical properties during osmodehydrofreezing of kiwi fruit. Innovative Food Science \& Emerging Technologies, 3(2), 191199.https://doi.org/10.1016/S1466-8564(02)00027-9

TELIS, V. R. N., MURARI, R. C. B. D. L.,YAMASHITA, F. 2004. Diffusion coefficients during osmotic dehydration of tomatoes in ternary solutions. Journal of Food Engineering, 61(2), 253-259. https://doi.org/10.1016/S02608774(03)00097-9

TORRES, J. D., TALENS, P., CAROT, J. M., CHIRALT, A., ESCRICHE, I. 2007. Volatile profile of mango (Mangifera indica L.) as affected by osmotic dehydration. Food Chemistry, 101(1), 219-228. https://doi.org/10.1016/j.foodchem.2006.01.020

UDDIN, M. B., AINSWORTH, P., İBANOĞLU, S. 2004. Evaluation of mass exchange during osmotic dehydration of carrots using response surface methodology. Journal of Food Engineering, 65(4), 473-477. https://doi.org/10.1016/j.jfoodeng.2004.02.007

VIANA, A. D., CORRÊA, J. L. G., JUSTUS, A. 2014. Optimisation of the pulsed vacuum osmotic dehydration of cladodes of fodder palm. International Journal of Food Science and Technology, 49(3), 726-732. https://doi.org/10.1111/ijfs.12357

VIEIRA, G.S., PEREIRA, L.M., HUBINGER, M.D. 2012. Optimization of osmotic dehydration process of guavas by response surface methodology and desirability function. International Journal of Food Science and Technology. 47(1), 132-140.https://doi.org/10.1111/j.1365-2621.2011.02818.x

WENG W., LIU, W., LIN, W. 2001. Studies on the optimum models of the dairy productKou Woan Lao using response surface methodology. Asian Australasian Journal of Animal Sciences, 14(10),14701476. http://dx.doi.org/10.5713/ajas.2001.1470

YADAV, B. S., YADAV, R. B., JATAIN, M. 2012. Optimization of osmotic dehydration conditions of peach. Journal of Food Science and Technology, 49(5), 547-555. http://dx.doi.org/10.1007/s13197-011-0298-z

ZAPATA, J.E.,CIRO,G.L., MARULANDA, P. 2016. Optimization of pulsed vacuum osmotic dehydration of the cape gooseberry (Physalis peruviana L.) using response surface methodology. Agronomia Colombiana, 34(2), 228-238. http://dx.doi.org/10.15446/agron.colomb.v34n2.54920 